\title{
Pengembangan Kompetensi Profesional Calon Guru PKn MI: Pemahaman tentang Paradigma Baru PKn
}

\author{
Nufikha Ulfah \\ IAIN Ponorogo \\ ulfahnufikha@gmail.com
}

\begin{abstract}
Abstrak
Pendidikan merupakan sebuah proses dimana guru membantu peserta didik ke dalam sebuah perubahan yang dianggap baik. Inti dari sebuah pendidikan ialah sebuah proses belajar mengajar. Guru sebagai pemegang peranan utama, dimana guru memandu sebuah proses pembelajaran dan menciptakan hubungan timbal balik Antara guru dan peserta didik dalam suasana belajar demi tercapainya tujuan pembelajaran. Pendidikan kewarganegaraan sebagai program kurikuler berfungsi sebagai wahana pengembangan karakter yang demokrasi dan bertanggung jawab. Melalui pembelajaran PKn di sekolah sebagai pusat pengembangan wawasan, sikap, dan keterampilan dalam kehidupan demokratis. Oleh karena itu, agar proses pembelajaran dan bimbingan dapat terarah dan mencapai yujuan yang telah ditetapkan maka seorang calon guru PKn MI harus mulai mengembangkan kompetensi profesionalnya yang berkenaan dengan kemampuan mengemas sebuah pembelajaran yang mencakup penguasaan materi pembelajaran bidang studi dan substansi keilmuan pada kurikulum mata pelajaran (materi, struktur, konsep serta pola pikir keilmuan yang mendukung PKn).

Tugas PKn dengan paradigma barunya (paradigma dalam konteks ini merupakan cara berpikir baru tentang PKn yang sifatnya mendasar seperti: materi pokok keilmuan, visi dan misi, serta model atau kerangka berpikir yang digunakan dalam proses pendidikan kewarganegaraan di Indonesia) yaitu mengembangkan pendidikan demokrasi dengan tiga fungsi pokoknya yaitu mengembangkan kecerdasan warga negara (civic intelligence), membina tanggung jawab warga negara (civic responsibility), dan mendorong partisipasi warga negara (civic participation). Seorang calon guru PKn MI wajib mempersiapkan kemampuannya dalam memahami paradigm baru PKn sehingga kelak dalam praktiknya kelak para calon guru PKn MI tidak lagi mengalami kesulitan dalam memilih dan menyusun materi serta menentukan model pembelajaran yang cocok untuk pokok bahasan tertentu.
\end{abstract}

Kata Kunci: Paradigma Baru PKn, Kompetensi Profesional 


\begin{abstract}
Education is a process by which teachers help learners into a change that is considered good. The essence of an education is a process of teaching and learning. Teachers as the main role-holders, where teachers guide a learning process and create mutual relationships between teachers and learners in the learning environment for the achievement of learning objectives. Civic education as a curricular program serves as a medium for the development of democratic and responsible character. Through Civic learning in schools as a center for the development of insights, attitudes, and skills in democratic life. Therefore, for the learning process and guidance can be directed and achieve the goals that have been determined then a candidate of Civics teacher of Madrasah Ibtidaiyah should begin to develop his/her professional competence related to the ability to package a lesson that includes mastery of learning materials in the field of study and the substance of science on the curriculum subjects (materials, structures, concepts and scientific minds that support the civic education).

The task of Civics with its new paradigm (the paradigm in this context is a new way of thinking about basic Civics such as: the subject matter of science, vision and mission, and the model or frame of mind used in the civic education process in Indonesia) that is to develop democratic education with three functions to develop civic intelligence, to cultivate civic responsibility, and to encourage citizen participation. A candidate of Civics teacher of Madrasah Ibtidaiyah must prepare his ability in understanding the new paradigm of Civics so that later in the future the candidate of Civics teacher of Madrasah Ibtidaiyah no longer have difficulty in selecting and arranging the material and determine the appropriate learning model for a particular subject.
\end{abstract}

Keywords: New Paradigm of Civics, Professional Competence

\section{A. PENDAHULUAN}

Pendidikan Kewarganegaraan merupakan mata pelajaran yang sudah mulai diajarkan kepada peserta didik jenjang SD/MI. Pembelajaran Pendidikan Kewarganegaraan pada setiap jenjang pendidikan merupakan bagian penting karena pada hakikatnya pendidikan merupakan upaya sadar yang dilakukan tidak hanya dari lembaga pendidikan formal melainkan dari suatu masyarakat dan peran pemerintah suatu Negara untuk menjamin kelangsungan hidup dan kehidupan generasi penerusnya. Oleh karena itu, dalam pembelajaran
Pendidikan Kewarganegaraan, khususnya dalam jenjang pendidikan dasar sebaiknya dikembangkan sebagai tatanan social yang kondusif atau memberi suasana bagi tumbuh kembangnya berbagai kualitias peserta didik. Sekolah sebagai bagian integral dari masyarakat perlu dikembangkan sebagai pusat pembudayaaan dan pemberdayaan peserta didik sepanjang hayat, yang mampu memberi keteladanan, membangun kemauan dan mengembangkan peserta didik dalam proses pembelajaran demokratis. Pendidikan Kewarganegaraan sebagai program kurikuler berfungsi sebagai 
wahana pengembangan karakter yang demokratis dan bertanggung jawab. Melalui pembelajaran PKn di sekolah sebagai pusat pengembangan wawasan, sikap, dan keterampilan dalam kehidupan demokratis. Oleh karena itu pengetahuan dan kemampuan seorang guru di SD/MI sangat penting guna mengetahui sejauh mana seorang siswa benar-benar telah mencapai tujuan pembelajaran PKn. Pendidikan tidak dapat lepas dari sebuah proses dimana guru membantu dalam perubahan peserta didik ke arah yang dianggap baik. Guru adalah suatu sebutan jabatan, posisi dan profesi bagi yang mengabdikan dirinya dalam bidang pendidikan melalui interaksi edukatif secara terpola, formal dan sistematis. ${ }^{1}$ Ditegaskan (UU No. 14 Tahun 2005, Pasal 1): "Guru adalah pendidik professional dengan tugas utama mendidik, mengajar, membimbing, mengarahkan melatih, menilai, dan mengevaluasi peserta didik pada pendidikan usia dini jalur pendidikan formal, pendidikan dasar, dan pendidikan menengah". Sejalan dengan hal tersebut dikemukakan pula (Kunandar, 2007 sebagaimana dikutip Damayanti, et al., 2017: 81) bahwa Pardigma guru yang semula hanya pengajar (teacher), kini beralih sebagai pelatih (Coach), pembimbing (counsellor), dan manajer belajar (learning manager). ${ }^{2}$

\footnotetext{
${ }^{1}$ Fitri Mulyani, "Konsep Kompetensi Guru Dalam Undang-Undang Nomor 14 Tahun 2005 Tentang Guru Dan Dosen (Kajian Ilmu Pendidikan Islam)," FKIP Garut Vol. 03; No. 01; 2009 (2009): 2.

2 Temi Damayanti, Stephani Raihana Hamdan, and Andhita Nurul Khasanah, "Kompetensi Guru Dalam Proses Pembelajaran Inklusi Pada Guru SD Negeri Kota Bandung," SCHEMA Vol. 3, No. 1, Mei 2017 (2017): 81.
}

Inti dari proses pendidikan ialah sebuah proses belajar mengajar. Pemegang peranan utama alam kegiatan belajar mengajar secara keseluruhan adalah guru. Dimana guru memandu sebuah proses pembelajaran dan menciptakan hubungan timbal balik antara guru dan peserta didik yang berlangsung dalam suasana belajar demi tercapainya tujuan pembelajaran. Oleh karena itu, agar proses pembelajaran dan bimbingan yang dilakukan guru dapat terarah dan mencapai tujuan yang telah ditetapkan, maka seorang guru harus memiliki dan menguasai kompetensikompetensi utama: kompetensi pedagogic, kepribadian, professional, dan kompetensi sosial $^{3}$ sebagaimana yang diamanatkan dalam Peraturan Pemerintah Republik Indonesia Nomor 19 Tahun 2005 tentang Standar Nasional Pendidikan bahwa pendidik harus memiliki kompetensi sebagai agen pembelajaran pada jenjang pendidikan anak usia dini, pendidikan dasar, dan menengah meliputi (1) kompetensi pedagogic; (2) kompetensi kepribadian; (3) kompetensi professional; dan (4) kompetensi social.

Kompetensi professional berkenaan dengan kemampuan seorang guru mengemas sebuah pembelajaran yang mencakup penguasaan materi pembelajaran bidang studi dan substansi keilmuan pada kurikulum mata pelajaran. Sebagaimana yang dikemukakan oleh Samana (1994) yang dikutip (Wahyudi, 2010: 108): "Guru yang berkualifikasi professional, yaitu guru yang tahu secara

\footnotetext{
${ }^{3}$ Wahyudi, "Standar Kompetensi Profesional Guru," Jurnal Pendidikan Sosiologi Dan Humaniora Vol. 1, No. 2, Oktober 2010 (2010): 107.
} 
mendalam tentang apa yang diajarkannya, cakap cara mengajarkannya secara efektif dan efisien." ${ }^{4}$ Berdasarkan pendapat tersebut, penulis bermaksud ingin memberikan sebuah gagasan kepada calon guru MI/SD agar terus berupaya mengasah kompetensi professional untuk memahami serta mendalami berbagai bidang studi/mata pelajaran terutama Pendidikan Kewarganegaraan sesuai dengan judul tulisan ini. Untuk memahami lebih lanjut tentang kompetensi professional guru, maka kajian lebih luas akan dibahas dalam sub pokok bahasan yang merupakan satu kesatuan dari kompetensi professional mengajarkan bahan bidang studi atau mata pelajaran Pendidikan Kewarganegaraan.

\section{B. METODE PENELITIAN}

Metode yang digunakan dalam tulisan ini menggunakan metode study literature atau kajian teoritik, memaparkan teoriteori yang berhubungan dengan judul.

\section{Tantangan Pendidik dan Pendidikan di Indonesia Kini}

Pendidikan merupakan sarana penting untuk meningkatkan kualitas sumber daya manusia dalam menjamin keberlangsungan pembangunan suatu bangsa dan negara. Menurut Pasal 1 Undang-undang No. 20 Tahun 2003 tentang Sisdiknas:

"Pendidikan pada hakikatnya adalah usaha sadar dan terencana untuk mewujudkan proses pembelajaran agar peserta didik secara aktif mengembangkan potensi dirinya untuk memiliki kekuatan spiritual

${ }^{4} 108$. keagamaan, pengendalian diri, kepribadian, kecerdasan, akhlak mulia, serta keterampilan yang diperlukan dirinya, masyarakat, bangsa dan negara".

Pendidikan yang dilaksanakan di Indonesia berdasarkan Pancasila dan UUD 1945 yang berakar pada nilai-nilai agama, kebudayaan nasional Indonesia dan tanggap terhadap tuntutan zaman. Pembekalan kepada peserta didik di Indonesia berkenaan dengan pemupukan nilai-nilai, sikap dan kepribadian yang sesuai dengan Pancasila dan UUD 1945, menumbuhkan sikap cinta tanah air, serta berwawasan kebangsaan yang luas dan dapat diandalkan oleh bangsa dan negaranya melalui Pendidikan Kewarganegaraan sebagai program kurikuler, yang merupakan salah satu mata kuliah wajib mulai Sekolah Dasar sampai Perguruan Tinggi. ${ }^{5}$

Globalisasi dan tantangan pendidikan nasional merupakan bagian yang tidak terpisahkan. Globalisasi dapat menjadi ancaman dan juga sekaligus tantangan, seperti dua sisi mata koin (negative dan positif. Sebagai ancaman, globalisasi membawa pengaruh yang negative terutama mengancam nilai-nilai budaya local dan spiritual yang menjadi ciri khas bangsa Indonesia yang disebabkan oleh gaya "keHollywood-an" yang meracuni masyarakat. Sebagai tantangan, jika globalisasi itu memberi pengaruh positif, maka kita harus mampu menyerapnya dengan baik, terutama pada hal-hal yang tidak berbenturan dengan nilai-nilai

\footnotetext{
${ }^{5}$ Bunyamin Maftuh, Internalisasi Nilai-Nilai Pancasila Dan Nasionalisme Melalui Pendidikan Kewarganegaraan (Bandung: UPI, 2008), 136.
} 
agama dan budaya kita. Budaya yang di Barat atau negara lain yang bernilai positif itu dapat diserap dan dipraktekkan di tengah proses pendidikan yang dilakukan, seperti penanaman budaya disiplin, kerja keras, kejujuran, penghargaan terhadap prestasi, kompetisi, kemandirian, law enforcement, demokrasi, dan lain-lain. Disinilah maka pendidikan (agama) dapat berperan dan harus mampu menyaring mana yang baik diikuti, dan mana yang buruk harus dihindari. ${ }^{6}$ Sebagai tantangan, jika globalisasi membawa dampak positif, maka kita harus menyerapnya dengan baik, terutama pada hal-hal yang berhubungan dengan nilai-nilai agama dan budaya kita. Dalam suasana globalisasi, kental dengan suasana kompetitif, maka dari itu perlu adanya persiapan diri, pembentukan kepribadian yang berkaitan dengan penyediaan SDM yang handal. Penyediaan ini meliputi kesiapan mental dan sekaligus kesiapan skills dan profesionalitas. Kaitannya dengan dunia pendidikan, tantangannya adalah bagaimana para guru mampu

\footnotetext{
6 "GLOBALISASI DAN TANTANGAN

PENDIDIKAN ISLAM MASA KINI*) (Respon Islam Terhadap Kemajuan Informasi, Komunikasi Dan Teknologi) Oleh : Drs. M. Ilham Masykuri

Hamdie, M.Ag - Penelusuran Google," accessed April 3, 2018,

https://www.google.com/search?source=hp\&ei=1irD W sb8CczZvgTigrfgAw\&q=+GLOBALISASI+DAN+ TANTANGAN+PENDIDIKAN+ISLAM+MASA+KI $\mathrm{NI}+* \% 29+\% 28 \mathrm{Respon+Islam+terhadap+Kemajuan+}$ Informasi\%2C+Komunikasi+dan+Teknologi\%29+Ole $\mathrm{h}+\% 3 \mathrm{~A}+$ Drs.+M.+Ilham+Masykuri++Hamdie\%2C+ M.Ag\&oq $=+$ GLOBALISASI+DAN+TANTANGAN+ PENDIDIKAN+ISLAM+MASA+KINI+*+\%29+\%28 Respon+Islam+terhadap+Kemajuan+Informasi $\% 2 \mathrm{C}+$ Komunikasi+dan+Teknologi\%29+Oleh+\%3A+Drs.+ M.+Ilham+Masykuri++Hamdie\%2C+M.Ag\&gs_l=ps $\mathrm{y}-$

ab.3...2166.2166.0.4692.1.1.0.0.0.0.0.0..0.0...0...1c.1. 64.psy-ab..1.0.0....0.Co7VvwZtYfs.
}

mempersiapkan peserta didik menjadi SDM yang mampu berkompetisi kelak yang dilandasi atas nilai-nilai fundamental Indonesia.

Kemajuan bangsa dan negara di masa yang akan datang salah satunya ditentukan oleh kualitas generasi muda saat ini. Pendidikan yang dikelola saat ini memberikan dampak bagaimana masa depan bangsa yang akan dikelola. Pendidikan yang berkualitas merupakan hal yang krusial dalam pembangunan bangsa yang memiliki SDM yang mantap. Guru yang professional menjadi peran utama dan factor terpenting dalam pendidikan yang berkualitas. Sangat dipahami bila saat ini pemerintah dan kita semua menggelisahkan kualitas pendidikan termasuk kualitas guru. Seperti apa sosok guru yang diharapkan dimasa yang akan datang?. Dalam buku yang berjudul "Menyiapkan Guru Masa Depan" (Rustad,. dkk hal 4., sebagaimana dikutip oleh Rohandi, 2015: 2), dipaparkan:

“..., guru masa kini dan masa depan harus benar-benar menyadari bahwa telah terjadi pergeseran dalam menetapkan tujuan pendidikan, yang semula pendidikan bertujuan menyiapkan lulusan siap pakai, harus digeser menuju lulusan yang mandiri, mampu berkolaborasi sebagai anggota masyarakat, mampu menalar, mampu menggunakan teknologi informasi, mampu memanfaatkan, dan mengembangkan aneka sumber belajar."7

Dengan demikian dalam konteks profesionalitas guru yang semula menjadi

\footnotetext{
${ }^{7}$ Rohandi, "Tantangan Pendidikan Guru Di Indonesia," 2015.
} 
sumber otoritas pengetahuan mengalami pergeseran menjadi guru sebagai fasilitator dan/atau mediator dituntut untuk kreatif dalam mengembangkan bidang keilmuan serta mengembangkan program pembelajaran yang bermakna.

\section{Bagaimana Calon Guru Dan Proses Pendidikannya?}

Animo generasi muda saat ini untuk melanjutkan pendidikan tinggi pada program kependidikan perlu mendapatkan sambutan yang baik, khususnya para lembaga penyelanggara program kependidikan. Beberapa penelitian mencoba mengelaborasi motivasi untuk menjadi guru (Bruinsma dan Jansen (2010) sebagaimana dikutip Rohandi, 2015: 2) bahwa motivasi untuk menjadi guru beragam mulai dari alasan ekonomi, kenyamanan dalam bekerja, professional (hasrat untuk bekerja sesuai dengan bidang yang diminatinya) sampai alasan kesediaan dan kerelaan untuk berkorban dalam ikut memikul tanggung jawab terhadap perkembangan anak. Selain itu terdapat motivasi lain yang melatarbelakangi yaitu pemberian tunjangan profesi guru yang jumlahnya satu kali gaji pokok, hal ini menjadikan profesi guru sebagai profesi yang semakin diminati oleh masyarakat. ${ }^{8}$

Kecintaan akan bidang kajian yang digelutinya juga menjadi faktor penting dan krusial, pendidikan guru sangat berperan dalam membangun motivasi instrinsik. Seperti penelitian yang dilakukan oleh Rots., dkk (2014) yang hasilnya menunjukkan bahwa calon guru yang memiliki motiviasi instrinsik yang

${ }^{8} 2$. kuat komitmennya terhadap tugas profesionalnya sebagai guru dapat diandalkan. Guru yang mencintai bidang ilmunya akan lahir guru yang selalu belajar untuk meningkatkan serta memperbaharui kemampuan yang berkaitan dengan profesionalitasnya dan wawasan keilmuannya. Guru masa depan adalah guru yang berjiwa ilmuwan dan sekaligus ilmuwan yang berjiwa guru. ${ }^{9}$

\section{Konsep Kompetensi Profesional}

Sebelum membahas lebih jauh terkait kompetensi professional, terlebih dahulu akan dibahas mengenai kompetensi. Kompetensi adalah seperangkat pengetahuan, keterampilan, dan perilaku yang harus dimiliki, dihayati, dan dikuasai oleh guru dalam melaksanakan tugas keprofesionalannya. ${ }^{10}$ Dalam Peraturan Pemerintah Nomor 19 Tahun 2005 disebutkan bahwa sebagai agen pembelajaran pendidik/guru harus memiliki kualifikasi akademik dan kompetensi, kompetensi yang dimaksudkan meliputi:
a. Kompetensi Pedagogik;
b. Kompetensi Kepribadian;
c. Kompetensi Profesional; dan
d. Kompetensi Sosial ${ }^{11}$
Hal ini ditegaskan dalam UndangUndang Nomor 15 Tahun 2005 tentang Guru dan Dosen Pasal 8: " Guru wajib memiliki kualifikasi akademik, kompetensi, $\quad$... $\quad$ serta memiliki kemampuan untuk mewujudkan tujuan

\footnotetext{
93.

${ }^{10}$ Undang-Undang Nomor 14 Tahun 2005 tentang Guru dan Dosen. Pasal 1, 10.

${ }^{11}$ Peraturan Pemerintah Nomor 19 Tahun 2005 tentang Standar Nasional Pendidikan
} 
pendidikan nasional". Kompetensi sebagaimana yang disebutkan di atas dibutuhkan dalam aktivitas pendidikan dan sebagai pedoman perilaku guru dalam melaksanakan tugas di sekolah maupun hubungannya dengan stakeholder bidang pendidikan. Dan kompetensi professional merupakan salah satu pilar yang pendukung peningkatan kualitas seiring dengan perkembangan lingkungan/masyarakat. ${ }^{12}$

Menurut KBBI, kata professional memiliki arti 1 . bersangkutan dengan profesi; 2. memerlukan kepandaian khusus untuk menjalankannya. ${ }^{13}$ Istilah profesional seringkali seseorang yang merupakan ahli dalam suatu bidang, ${ }^{14}$ professional atau profession (dalam Bahasa Inggris) mengandung arti sama dengan occupation atau pekerjaan yang memerlukan keahlian yang diperoleh melalui pendidikan atau latihan khusus. Bagi guru, profesi dikaitkan dengan dengan tugas-tugas pendidikan dan pengajaran baik di dalam maupun di luar kelas. Jadi dapat disimpulkan bahwa, guru yang professional ialah guru yang memiliki keahlian khusus yang berkaitan dengan profesinya sebagai tenaga professional yang mampu melaksanakan tugas-tugasnya yaitu mendidik dan mengajar di mana hal ini merupakan keahlian yang didapat melalui pendidikan khusus yaitu pendidikan guru. Guru sebagai tenaga professional menurut undang-undang mengandung arti bahwa pekerjaan guru hanya dapat dilakukan

\footnotetext{
12 "Standar Kompetensi Profesional Guru," 107.

13 "Kamus Besar Bahasa Indonesia," n.d., https://www.kbbi.web.id/profesional.

14 "Wikipedia Bahasa Indonesia," n.d., id.wikipedia.org/wiki/Profesional.
}

oleh seseorang yang mempunyai kualifikasi akademik, kompetensi, dan sertifikat pendidik sesuai dengan jenis dan jenjang pendidikan tertentu.

\section{Bagaimana Kompetensi Professional Guru PKn Selama Ini?}

Kompetensi profesional guru PKn selama ini dapat dilihat dari beberapa hasil penelitian, diantaranya penelitian yang dilakukan oleh Ditjen Peningkatan Mutu Pendidik dan Tenaga Kependidikan (PMPTK) Depdiknas Tahun 2008 terhadap guru-guru yang lolos sertifikasi menunjukan nilai rata-rata berkisar antara $52-64 \%$ yaitu 64,34\%, kompetensi professional guru yang dinyatakan lulus sertifikasi melalui penilaian portofolio tidak menunjukan peningkatan mutu guru, bahkan menunjukkan adanya penurunan sebesar 19,59\%. Jadi dapat ditarik kesimpulan bahwasanya guru yang dinyatakan lolos sertifikasi belum menunjukkan adanya peningkatan kompetensi professional seperti yang diharapkan (Baedowi, 2009). ${ }^{15}$ Hasil kajian mengenai kompetensi professional pada guru di 56 sekolah, yang terdiri dari 32 SD/MI dan 24 SMP/MTs yang ada di 9 provinsi yang dilakukan oleh Staf Ahli Mendiknas (2007) menunjukkan bahwa kegiatan pembelajaran masih bersifat konvensional: berpusat pada guru (teacher centered), kurang mendorong siswa mengembangkan potensi, dan cenderung lebih menekankan pada penyampaian materi pelajaran (subject matters oriented). Kelemahan umum lainnya dalam

\footnotetext{
${ }^{15}$ Winarno, Pembelajaran Pendidikan Kewarganegaraan: Isi, Strategi, Dan Penilaian (Jakarta: Bumi Aksara, 2014), 52.
} 
pembelajaran PKn adalah proses belajar yang hanya menyentuh pada kemampuan berpikir tingkat rendah. Terperangkapnya pembelajaran berpikir tingkat rendah disebabkan karena pengaruh buku-buku pelajaran yang cenderung isinya lebih mennekankan pada ranah kognitif, seperti hafalan mengenai konsep, definisi, peristiwa dan kejadian (fakta). Buku teks PKn yang mampu menyajikan pengetahuan dalam bentuk proposisi (hubungan antar konsep) dan teori sebuah fenomena amat jarang ditemukan. Kemudian, di susu lain, materi PKn secara umum khususnya yang berkaitan dengan nilai dan sikap bersifat "the great ought", cenderung dogmatis dan normatif seperti: Pancasila, UUD 1945, Sumpah Pemuda, Proklamasi Kemerdekaan, Peraturan Perundang-undangan sehingga mau tidak mau guru PKn harus menyajikan materi yang demikian dalam rangka membentuk peserta didik sebagai warga Negara yang sejalan dengan kehidupan bangsa dan negara. Terhadap materi yang demikian, Gross dalam Somantri (2001) membedakan adanya jenis sikap guru PKn yang terjebak dalam menghadapi materi pembelajaran seperti ini, yaitu extreme propagandist ialah guru yang bersikap bertentangan dengan tujuan PKn, guru yang tidak bias melatih siswa untuk berpikir logis, kritis, dan analitis, tetapi menyuruh siswa untuk meneripa apa saja yang diajarkan dan tercantum dalam buku pelajaran sehingga siswa berpikir berdasar emosi bukan rasio; guru PKn yang bersifat neutral tidak mampu memfasilitasi peserta didik dalam proses pengambilan keputusan sehingga pikirannya terapung-apung dan guu PKn
Nampak bersikap masa bodoh dengan kandungan nilai ajar PKn. Ia menyampaikan bahan ajar PKn sebatas citizenship transmissions; dan guru PKn yang dedicate and well informed teachers adalah mereka yang memiliki itikad baik dan pengabdian yang besar kepada bangsa dan negara. Guru PKn yang demikian bersedia memberi bimbingan kepada siswa dengan menunjukkan bahan maupun sumber pengetahuan PKn serta apa yang seharusnya dapat dimiliki peserta didik, sehingga peserta didik memiliki komitmen dan tanggung jawab yang kuat bagi kelangsungan hidup bangsa dan negara. ${ }^{16}$

Sejalan dengan yang telah dijabarkan di atas, pembahasan oleh Tim Civic Education Research Project, Jurusan Civics-Hukum FKIS IKIP Bandung terhadap buku Civic (PKn) yang dipergunakan di SD-SLTA menunjukkan adanya kesamaan pendapat bahwa Civics disamakan dengan: (a) Sejarah (Bukubuku untuk SD); (b) Sejarah Kebangkitan Nasional, Sejarah Perjuangan Mempertahankan Kemerdekaan, UUD dan Pancasila (Kurikulum SMP 1968, Buku Kewarganegaraan untuk SMP); dan (c) UUD dan Pancasila (Kurikulum SMA 1968). Kekaburan dan kekeliruan terhadap Civics bukan hanya terjadi di Indonesia, melainkan di negara pelopor pelajaran civic yaitu Amerika Serikat, hal ini dilukiskan oleh Smith (Somantri, 2001: 279) bahwa saat ini banyak guru yang masih belum mengetahui dengan jelas tujuan dari pelajaran Civics disebabkan karena Civics memasukan berbagai macam bahan yang diperkirakan dapat

\footnotetext{
${ }^{16} 56-57$.
} 
menumbuhkan ciri-ciri warga negara yang baik, sehingga bahan pelajarannya menjadi kurang terintegrasi (loosly integrated). Bennet dan Piper (1968: 7-13) mengungkapkan hal berkaitan dengan terlalu luasnya tujuan PKN/Civic Education: "Objectives were frequently stated in the vaguest language. They sought "to develop in the student an attitude of mind", "or to inculcate mental fibre", or to produce "dynamic citizenship". Very obviously, such objectives never be evaluated". Karena terlalu luasnya tujuan tersebut, maka logis apabila timbul kekeliruan dan kekaburan terhadap mata pelajaran ini. ${ }^{17}$

Pusat Kurikulum (2007) melakukan kajian kebijakan kurikulum Pendidikan Kewarganegaraan yang hasilnya menyebutkan bahwa pemahaman guru PKn terhadap Standar Kompetensi dan Kompetensi Dasar mapel PKn amat beragam, hal ini terjadi karena latar belakang pendidikan, daerah, kapasitas, serta kompetensi dalam memahami dan memaknai SK dan KD dalam implementasi pembelajaran. ${ }^{18}$ Berdasarkan kelemahamkelemahan yang telah dipaparkan di atas, dapat disimpulkan bahwasanya calon guru MI yang akan mengampu mata pelajaran Pendidikan Kewarganegaraan hendaknya mempersiapkan amunisi (kompetensi professional) sebagai senjata utama yang mampu:

a. memahami materi, struktur, konsep, dan pola piker keilmuan yang

\footnotetext{
${ }^{17}$ Muhammad Numan Somantri, Menggagas Pembaharuan Pendidikan IPS (Bandung: PT Remaja Rosdakarya, 2001), 78-80.

${ }^{18}$ Pembelajaran Pendidikan Kewarganegaraan: Isi, Strategi, Dan Penilaian, 58.
}

mendukung mata pelajaran Pendidikan Kewarganegaraan;

b. memahami substansi Pendidikan Kewarganegaraan yang meliputi pengetahuan kewarganegaraan (civic knowledge), nilai dan sikap kewarganegaraan (civic dispositions), dan keterampilan kewarganegaraan (civic skills); dan

c. menunjukkan manfaat mata pelajaran Pendidikan Kewarganegaraan. ${ }^{19}$

\section{Apa saja yang perlu dimiliki Guru PKn?}

Sama dengan guru mata pelajaran lainnya bahwa pada dasarnya seorang guru PKn MI harus memiliki kompetensi professional yaitu kemampuan guru PKn untuk menguasai materi, struktur, konsep, pola piker keilmuan yang mendukung PKn. Kompetensi professional yang berkaitan dengan keilmuan pokok seorang guru PKn adalah memiliki pemahaman yang benar tentang materi, struktur, konsep serta pola pikir keilmuan yang mendukung mata pelajaran Pendidikan Kewarganegaraan. Apa saja materi, konsep, dan keilmuan yang mendukung Pendidikan Kewarganegaraan? Menurut Somantri (2001) bahan atau materi Pendidikan Kewarganegaraan pada dasarnya bersumber dari Ilmu Kewarganegaraan (IKn) dengan diperluas lagi dengan sumber-sumber lintas disiplin ilmu dari berbagai disiplin ilmu lainnya sperti sosial, humaniora, sains, teknologi, seni budaya, bahkan nilai agama serta masalah kemasyarakatan. Pendidikan Kewarganegaraan merupakan seleksi dan adaptasi dari lintas disiplin ilmu-ilmu sosial, ilmu kewarganegaraan, humaniora,

${ }^{19} 52$. 
kegiatan dasar manusia yang diorganisasi dan disajikan secara psikologis dan ilmiah untuk mencapai salah satu tujuan pendidikan IPS karena PKn termasuk dalam ilmu sosial.

Ilmu Kewarganegaraan merupakan sub disiplin ilmu politik yang merupakan terjemahan dari istilah civic, yaitu suatu studi yang berkaitan dengan tugas pemerintah serta hak dan kewajiban warga negara (demokrasi politik). Dalam Dictionary of Education disebutkan bahwa "Civics is element of political science or branch of political science dealing with the rights and duties of citizen". Civics merupakan bagian dari ilmu politik, adapun fokus dari civics yaitu demokrasi politik. Dalam proses pendidikan, upaya penerapan civics melalui program pendidikan kewarganegaraan (civic education) muatan atau materi pokoknya adalah demokrasi politik yang ditujukan kepada peserta didik sebagai bagian warga negara yang bersangkutan. Di Indonesia, ide fundamental yang berkaitan dengan demokrasi politik untuk menyusun bahan PKn yaitu sebagaimana yang tertuang dalam UUD 1945.

Menurut Winataputra (2001), secara konseptual pendidikan kewarganegaraan atau citizenship education merupakan bidang kajian ilmiah pendidikan dengan disiplin ilmu sosial yang bersifat "lintasbidang keilmuan" yang berintikan ilmu politik yang secara pragmatik saling memiliki keterpautan yang bersifat komplementatif dengan pendidikan IPS secara keseluruhan. Hal ini berarti bahwa pendidikan kewarganegaraan berpijak pada ilmu politik serta salah satu dimensi dari social studies adalah citizenship education khususnya dalam upaya pengembangan intelligent social actor. Berdasarkan kedua pendapat pakar tersebut, menyiratkan bahwa PKn berdiri di atas dua disiplin ilmu, yaitu ilmu politik dimana Ilmu Kewarganegaraan sebagai bahan dasarnya, serta social studies dimana citizenship education merupakan intinya yang diorganisasikan secara psikologis dan ilmiah untuk kepentingan pembelajaran. Kemudian dari situ kita dapat mengemukakan dua kedudukan dari civic education. Pertama, civic education sebagai mata pelajaran yang berdiri sendiri, yang pijakan utamanya ialah konsep-konsep ilmu politik dengan dimensi "political education". Kedua, civic education sebagai esensi dari pembelajaran disiplin ilmu sosial dalam rangka social studies. ${ }^{20}$

Berdasarkan permasalahan yang telah dijabarkan, perlu diperhatikan bahwa seorang calon guru MI yang akan mengampu mata pelajaran Pendidikan Kewarganegaraan sudah semestinya "matang" dalam memahami ranah materi, konsep, serta keilmuan yang mendukung pendidikan kewarganegaraan agar guru tidak bingung maupun overlap pada saat perencanaan (penyusunan silabus dan RPP) dan saat proses pembelajaran. Diharapkan kepada calon guru professional untuk bisa menganalisis dan menerapkan konsep-konsep PKn di MI secara terintegrasi dalam pembelajaran. Hal ini menjadi penting bagi seorang calon guru PKn MI yang professional untuk memahami atau memiliki kemampuan tersebut, karena seringkali guru pemula mengalami kesulitan dalam menentukan,

\footnotetext{
${ }^{20} 64-67$.
} 
memilih dan mempertimbangkan materi pembelajaran PKn yang sesuai dengan perkembangan ilmu pengetahuan dan tuntutan perkembangan zaman.

Pendidikan Kewarganegaraan (civic education) memperkenalkan adanya 3 substansi pokok atau komponen yang harus dikuasai siswa dalam proses pembelajaran, yaitu pengetahuan kewarganegaraan (civic knowledge), keterampilan/kecakapan kewarganegaraan (civic skills), serta nilai dan sikap kewarganegaraan (civic dispositions). Ketiga komponen tersebut dikemukakan oleh Branson (1999) sebagai berikut.

"What are essential components of a good civic education? There are three essential components: civic knowledge, civic skills, and civic dispositions. The first essential component of civic education is civic knowledge that concerned with the content or what citizens ought to know; the subject matter, if you will. The second essential component of civic education in a democratic society is civic skills: intellectual and participatory skills. The third essential component of civic education , civic dispositions, refers to tha traits of private and public character essential to the maintenance and improvement of constitutional democracy." 21

Pendapat yang dikemukakan Branson dapat dimaknai dalam komponen pertama pengetahuan kewarganegaraan (civic knowledge) berkaitan dengan kandungan atau isi yang seharusnya

${ }^{21} 68$. diketahui oleh warga negara. Komponen kedua, keterampilan/kecakapan kewarganegaraan (civic skills) yang meliputi kecakapan intelektual dan kecakapan partisipasi berkaitan dengan kemampuan warga negara dalam mempraktekkan hak dan menunaikan kewajiban sebagai anggota masyarakat demokratis. Komponen ketiga sikap watak kewarganegaraan (civic dispositions) mengisyaratkan perlunya warga negara memiliki karakter privat maupun karakter public bagi pemeliharaan dan pengembangan demokrasi konstitusional. Jadi siswa tidak hanya menguasai dari segi pengetahuan saja akan tetapi mereka mampu memprektekkan komponen kedua serta mengartikulasikan komponen ketiga.

Ketiga komponen pokok pendidikan kewarganegaraan nantinya akan tercermin dalam pemilihan bahan ajar, pelaksanaan pembelajaran dan penilaian pembelajaran. Kompetensi professional guru diperlukan untuk menentukan bahan ajar akan yang dikembangkan, bahan ajar apa saja yang termasuk civic knowledge, civic skills, dan civic disposition; model pembelajaran yang seperti apa yang dapat dikembangkan untuk ketiga komponen tersebut; serta bentuk penilaian apa saja yang sesuai untuk mengukur pengetahuan kewarganegaraan (civic knowledge), keterampilan/kecakapan

kewarganegaraan (civic skills), dan nilai dan sikap kewarganegaraan (civic dispositions). Jadi merupakan hal yang sangat esensial bagi seorang calon guru PKn MI untuk memahami ketiga komponen pendidikan kewarganegaraan. Selain dari penguasaan terhadap ketiga komponen tersebut, menjadi keharusan 
bagi seorang calon guru PKn MI memahami manfaat dan tujuan dari pendidikan kewarganegaraan.

Perlu diketahui bahwa pendidikan kewarganegaraan memiliki dimensi ontologi, epistemologi, dan aksiologi (Winataputra, 2001 sebagaimana dikutip Winarno, 2014: 69). ${ }^{22}$ Ontologi PKn berkembang dari konsep "civics", yang kemudian diakui secara akademis sebagai embrio "civic education" menurut ahli ilmu politik Chreshore (1886) filsafat keilmuan PKn berasal dari ilmu politik khususnya berkaitan dengan konsep "political democracy", yang selanjutnya di Indonesia diadaptasi menjadi "pendidikan kewarganegaraan". Dari sudut pandang dimensi epistemologi menurut Barr., et al (1978) PKn sebagai suatu bidang keilmuan merupakan salah satu pengembangan dari lima tradisi "social studies" yakni "citizenship knowledge". ${ }^{23}$ Adapun manfaat dari pendidikan kewarganegaraan berarti berbicara mengenai aksiologi yang dalam filsafat ilmu aspek aksiologi berkaitan dengan masalah untuk apa ilmu dikembangkan dan adakah kaitannya dengan normanorma moral yang ada. Jadi dimensi aksiologi berbicara mengenai kegunaan ilmu dalam kehidupan, yaitu pendidikan kewarganegaraan sebagai model pembelajaran nilai bagi pengembangan nilai-nilai karakter warga negara. Kemudian Sapriya (2007) menjelaskan bahwa PKn sebagai ilmu memiliki dua tugas (1) bidang telaah untuk membangun body of knowledge dan (2) pengembangan

\footnotetext{
${ }^{22} 69$.

${ }^{23}$ H. Udin S. Winataputra and M. Sapriya, "Paradigma Baru PKn Di SD/MI," n.d., 13.
}

untuk transformasi konsep, nilai, dan keterampilan kewarganegaraan. ${ }^{24}$

\section{Paradigma Baru Pendidikan} Kewarganegaraan

Sebelum membahas paradigma baru pendidikan kewarganegaraan pada jenjang SD/MI di Indonesia, apa dan mengapa perlu mengembangkan paradigma baru PKn? Terlebih dahulu perlu dibatasi bahwa paradigma dalam konteks ini merupakan hal-hal yang bersifat mendasar seperti: materi pokok keilmuan, visi dan misi, serta model atau kerangka berpikir yang digunakan dalam proses pendidikan kewarganegaraan di Indonesia. Pengertian paradigma kadangkadang disederhanakan sebagai cara berpikir. Jadi paradigma baru PKn merupakan cara berpikir baru tentang PKn. Sejalan dengan dinamika perkembangan kehidupan berbangsa dan bernegara yang ditandai oleh semakin terbukanya persaingan antarbangsa yang semakin ketat maka bangsa Indonesia mulai memasuki era reformasi di berbagai bidang menuju kehidupan masyarakat yang lebih demokratis. Pendidikan kewarganegaraan sebagai salah satu mata pelajaran di persekolahan perlu menyesuaikan diri sejalan dengan kebutuhan dan tuntutan masyarakat guna menuju masyarakat madani (civil society). Bangsa Indonesia yang saat ini tengah mengalami suatu perubahan diharapkan bergerak ke arah pendewasaan hingga terbentuknya masyarakat yang betul-betul demokratis, religius, beradab, bersatu, dan berkeadilan sosial sesuai dengan konsep, nilai, norma dan moralitas yang tersurat

${ }^{24}$ Winataputra and Sapriya, 69. 
dan tersirat dalam Pancasila dan UUD 1945.25

Pendidikan

kewarganegaraan

memiliki tugas untuk mempersiapkan para peserta didik menjadi warga negara yang cerdas dan baik (be good and smart citizen). Warga negara yang dimaksud adalah warga negara yang menguasai pengetahuan kewarganegaraan (civic knowledge), mengartikulasikan keterampilan/kecakapan

kewarganegaraan (civic skills), dan memiliki karakter kewarganegaraan (civic dispositions). Bagi bangsa Indonesia ukuran warga negara yang baik tentunya sangat dipengaruhi oleh ideologi nasional yaitu Pancasila, dimana Pancasila memiliki fungsi sebagai acuan/landasan/dasar dalam kehidupan berbangsa dan bernegara.

Pendidikan kewarganegaraan saat ini perlu merevitalisasi pembangunan karakter bangsa yang sejak Proklamasi Kemerdekaan RI mejadi prioritas, agar sesuai dengan arah dan pesan konstitusi negara RI. Proses pembangunan karakter bangsa (national character building) diharapkan mengarah pada penciptaan suatu masyarakat Indonesia yang mampu menempatkan demokrasi dalam kehidupan bangsa dan negara sebagai titik sentral. Oleh sebab itu, pembangunan karakter bangsa kembali dirasakan sebagai kebutuhan yang mendesak sekaligus guna menghadapi tantangan era globalisasi dan tentunya perlu adanya sebuah paradigma baru atau pola pikir yang baru.

PKn dengan paradigma baru dikatakan sebagai PKn yang bermutu

\footnotetext{
${ }^{25}$ Winataputra and Sapriya, 1.5.
}

karena memiliki pengetahuan kewarganegaraan (civic knowledge) yang berbasis pada keilmuan yang jelas dan relevan bagi masyarakat demokratis, memiliki keterampilan kewarganegaraan (civic skills), dan karakter kewarganegaraan (civic dispositions) yang mampu mengembangkan pembangunan karakter bangsa, pemberdayaan warga negara dan masyarakat kewargaan. PKn yang bermutu inilah merupakan jati diri PKn yang mengacu pada tiga komponen seperti yang telah disebutkan sebelumnya. PKn di sekolah tidak hanya memberikan kemampuan untuk menghapal dan bukan untuk berpikir secara aktif sehingga hasilnya kurang bermakna (Muchtar Buchori, 2003 dalam Kompas sebagaimana dikutip oleh Cholisin). ${ }^{26}$ Sapriya dan Winataputra (2007) menguraikan tugas PKn di MI/SD dengan paradigma barunya mengembangkan pendidikan demokrasi yang mengemban tiga fungsi pokok, yakni mengembangkan kecerdasan warga negara (civic intelegence), membina tanggung jawab warga negara (civic responsibility) dan mendorong partisipasi warga negara (civic

\footnotetext{
26 "PENGEMBANGAN PARADIGMA BARU PENDIDIKAN KEWARGANEGARAAN (CIVIC EDUCATION) DALAM PRAKTEK PEMBELAJARAN KURIKULUM BERBASIS KOMPETENSI* - Penelusuran Google," accessed April 27, 2018,

https://www.google.com/search?source=hp\&ei=urniW tG_B4S08QXmh5zwDg\&q=PENGEMBANGAN+PA RADIGMA+BARU+PENDIDIKAN+KEWARGANE GARAAN+\%28CIVIC+EDUCATION\%29+DALAM +PRAKTEK+PEMBELAJARAN+KURIKULUM+B ERBASIS+KOMPETENSI*+\&oq=PENGEMBANG AN+PARADIGMA+BARU+PENDIDIKAN+KEWA RGANEGARAAN+\%28CIVIC+EDUCATION\%29+ DALAM+PRAKTEK+PEMBELAJARAN+KURIKU LUM+BERBASIS+KOMPETENSI*+\&gs_l=psyab.3...18745.18745.0.21493.1.1.0.0.0.0.0.0..0.0...0...1. 1.64.psy-ab..1.0.0...0.173Tm0DYtWo.
} 
participation). ${ }^{27}$ Oleh karena itu secara sadar dan terencana peserta didik sesuai dengan perkembangan psikologis dan konteks kehidupannya secara sistemik difasilitasi untuk belajar berkehidupan demokrasi secara utuh, yakni belajar tentang demokrasi (learning about democracy), belajar dalam iklim dan melalui proses demokrasi (learning through democracy), dan belajar untuk membangun demokrasi (learning for democracy). ${ }^{28}$

Bagaimana mengembangkan warga negara yang demokratis melalui tiga fungsi pokoknya itu? Untuk mengembangkan masyarakat demokratis melalui pendidikan kewarganegaraan diperlukan suatu strategi dan pendekatan pembelajaran khusus yang sesuai dengan paradigma baru PKn yakni model pembelajaran berbasis portofolio atau lebih dikenal dengan proyek-belajar kewarganegaraan yang memfokuskan pada kegiatan belajar siswa aktif (active students learning) dan pendekatan inkuiri (inquiry approach). Adapun karakteristik dari model ini: membelajarkan dan melatih siswa berpikir kritis, membawa siswa mengenal, memilih dan memecahkan masalah, melatih siswa dalam berpikir sesuai dengan metode ilmiah dan keterampilan sosial lain yang sejalan dengan pendekatan inkuiri. Sehingga pembelajaran PKn dengan paradigma lama yang terkesan menjejali siswa dengan kemampuan kognisi menjadi

\footnotetext{
${ }^{27}$ Winataputra and Sapriya, "Paradigma Baru PKn Di SD/MI," 1.1 .

${ }^{28}$ Udin S. Winataputra, "Diskursus Aktual Tentang Paradigma Pendidikan Kewarganegaraan (PKn) Dalam Konteks Kurikulum 2013," Bahan Diskusi Dalam Semnas PKn-AP3KnI, 2014, 4.
}

seimbang dengan kolaborasi antara kemampuan kognitif, afektif, dan psikomotor.

Bagi calon guru PKn MI ataupun guru pemula, perlu adanya kemampuan dalam memahami kebutuhan kualitas WNI yang demokratis dan mampu membelajarkan PKn untuk kewarganegaraan yang demokratis yang didukung dengan kemampuan dasar memilih dan menyusun materi serta menentukan model pembelajaran yang cocok untuk pokok bahasan tertentu. Dengan memahami dan menguasai materi diharapkan Anda akan terbantu dan tidak mengalami kesulitan dalam mengusai materi dan membelajarkan PKn yang sesuai dengn kebutuhan dan tuntutan masyarakat saat ini. Dengan demikian, kemampuan Anda dalam menerapkan model pembelajaran PKn semakin kaya yang berimplikasi pada para siswa akan semakin menyenangi belajar PKn.

\section{PENUTUP}

\section{Simpulan}

Seorang calon guru PKn MI harus memiliki kompetensi professional yaitu kemampuan guru PKn untuk menguasai materi, struktur, konsep, pola piker keilmuan yang mendukung PKn. Kompetensi professional yang berkaitan dengan keilmuan pokok seorang guru PKn adalah memiliki pemahaman yang benar tentang materi, struktur, konsep serta pola pikir keilmuan yang mendukung mata pelajaran Pendidikan Kewarganegaraan. Hal ini menjadi penting bagi seorang calon guru PKn MI yang professional untuk memahami atau memiliki kemampuan tersebut, karena seringkali guru pemula 
mengalami kesulitan dalam menentukan, memilih dan mempertimbangkan materi pembelajaran PKn yang sesuai dengan perkembangan ilmu pengetahuan dan tuntutan perkembangan zaman.

Pendidikan kewarganegaraan sebagai salah satu mata pelajaran di persekolahan perlu menyesuaikan diri sejalan dengan kebutuhan dan tuntutan masyarakat guna menuju masyarakat madani (civil society). Pendidikan kewarganegaraan memiliki tugas untuk mempersiapkan para peserta didik menjadi warga negara yang cerdas dan baik (be good and smart citizen). Warga negara yang dimaksud adalah warga negara yang menguasai pengetahuan kewarganegaraan (civic knowledge), mengartikulasikan keterampilan/kecakapan

kewarganegaraan (civic skills), dan memiliki karakter kewarganegaraan (civic dispositions). PKn dengan paradigma barunya mengembangkan pendidikan demokrasi yang mengemban tiga fungsi pokok, yakni mengembangkan kecerdasan warga negara (civic intelegence), membina tanggung jawab warga negara (civic responsibility) dan mendorong partisipasi warga negara (civic participation).

Bagi calon guru PKn MI ataupun guru pemula, perlu adanya kemampuan dalam memahami kebutuhan kualitas WNI yang demokratis dan mampu membelajarkan PKn untuk kewarganegaraan yang demokratis yang didukung dengan kemampuan dasar memilih dan menyusun materi serta menentukan model pembelajaran yang cocok untuk pokok bahasan tertentu. Dengan memahami dan menguasai materi diharapkan Anda akan terbantu dan tidak mengalami kesulitan dalam mengusai materi dan membelajarkan PKn yang sesuai dengn kebutuhan dan tuntutan masyarakat saat ini.

\section{DAFTAR PUSTAKA}

Damayanti, Temi, Stephani Raihana Hamdan, and Andhita Nurul Khasanah. "Kompetensi Guru Dalam Proses Pembelajaran Inklusi Pada Guru SD Negeri Kota Bandung." SCHEMA Vol. 3, No. 1, Mei 2017 (2017): 79-88.

"GLOBALISASI DAN TANTANGAN PENDIDIKAN ISLAM MASA KINI*) (Respon Islam Terhadap Kemajuan Informasi, Komunikasi Dan Teknologi) Oleh : Drs. M. Ilham Masykuri Hamdie, M.Ag Penelusuran Google." Accessed April 3, 2018. https://www.google.com/search?s ource $=\mathrm{hp} \& \mathrm{ei}=1 \mathrm{irDWsb8C}$ czZvgTigr fgAw\&q=+GLOBALISASI+DAN+TA NTANGAN+PENDIDIKAN+ISLAM+ MASA+KINI+*+\%29+\%28Respon+I slam+terhadap+Kemajuan+Informa si\%2C+Komunikasi+dan+Teknolog i\%29+Oleh+\%3A+Drs.+M.+Ilham+ Masykuri++Hamdie\%2C+M.Ag\&oq $=+$ GLOBALISASI+DAN+TANTANGA $\mathrm{N}+\mathrm{PENDIDIKAN}+\mathrm{ISLAM}+\mathrm{MASA}+\mathrm{KI}$ $\mathrm{NI}+{ }^{*}+\% 29+\% 28 \mathrm{Respon}+$ Islam+ter hadap+Kemajuan+Informasi $\% 2 \mathrm{C}+$ Komunikasi+dan+Teknologi\%29+0 leh+\%3A+Drs.+M.+Ilham+Masykur $\mathrm{i}++$ Hamdie $\% 2 \mathrm{C}+\mathrm{M}$.Ag\&gs_l=psyab.3...2166.2166.0.4692.1.1.0.0.0.0. $0.0 . .0 .0 \ldots . . . .1 \mathrm{c} .1 .64$.psyab..1.0.0...0.Co7VvwZtYfs.

"Kamus Besar Bahasa Indonesia," n.d. https://www.kbbi.web.id/profesio nal.

Maftuh, Bunyamin. Internalisasi Nilai-Nilai Pancasila Dan Nasionalisme Melalui Pendidikan Kewarganegaraan. Bandung: UPI, 2008. 
Mulyani, Fitri. “Konsep Kompetensi Guru Dalam Undang-Undang Nomor 14 Tahun 2005 Tentang Guru Dan Dosen (Kajian Ilmu Pendidikan Islam)." FKIP Garut Vol. 03; No. 01; 2009 (2009): 1-8.

"PENGEMBANGAN PARADIGMA BARU PENDIDIKAN

KEWARGANEGARAAN (CIVIC EDUCATION) DALAM PRAKTEK PEMBELAJARAN KURIKULUM BERBASIS KOMPETENSI* Penelusuran Google." Accessed April 27, 2018.

https://www.google.com/search?s ource $=$ hp\&ei=urniWtG_B4S08QXm h5zwDg\&q=PENGEMBANGAN+PAR ADIGMA+BARU+PENDIDIKAN+KE WARGANEGARAAN+\%28CIVIC+ED UCATION\%29+DALAM+PRAKTEK+ PEMBELAJARAN+KURIKULUM+BE RBASIS+KOMPETENSI*+\&oq=PEN GEMBANGAN+PARADIGMA+BARU +PENDIDIKAN+KEWARGANEGARA AN+\%28CIVIC+EDUCATION\%29+ DALAM+PRAKTEK+PEMBELAJARA $\mathrm{N}+\mathrm{KURIKULUM}+\mathrm{BERBASIS}+\mathrm{KOMP}$ ETENSI*+\&gs_l=psyab.3...18745.18745.0.21493.1.1.0.0. $0.0 .0 .0 . .0 .0 \ldots . . .1 .1 .64 . p s y-$ ab..1.0.0....0.173Tm0DYtWo.

Rohandi. "Tantangan Pendidikan Guru Di Indonesia," 2015.

Somantri, Muhammad Numan. Menggagas Pembaharuan Pendidikan IPS. Bandung: PT Remaja Rosdakarya, 2001.

Wahyudi. "Standar Kompetensi Profesional Guru." Jurnal Pendidikan Sosiologi Dan Humaniora Vol. 1, No. 2, Oktober 2010 (2010): 107-19.

"Wikipedia Bahasa Indonesia," n.d. id.wikipedia.org/wiki/Profesional.

Winarno. Pembelajaran Pendidikan Kewarganegaraan: Isi, Strategi, Dan
Penilaian. Jakarta: Bumi Aksara, 2014.

Winataputra, H. Udin S., and M. Sapriya. "Paradigma Baru PKn Di SD/MI," n.d.

Winataputra, Udin S. “Diskursus Aktual Tentang Paradigma Pendidikan Kewarganegaraan (PKn) Dalam Konteks Kurikulum 2013." Bahan Diskusi Dalam Semnas PKn-AP3KnI, 2014. 